\title{
BUDGET PROCEDURES AND FISCAL PERFORMANCE: EVIDENCE FROM OECD COUNTRIES IN THE WAKE OF THE CRISIS
}

\author{
Yulia Kasperskaya
}

Ramon Xifré 
The Public-Private Sector Research Center is a Research Center based at IESE Business School. Its mission is to develop research that analyzes the relationships between the private and public sectors primarily in the following areas: regulation and competition, innovation, regional economy and industrial politics and health economics.

Research results are disseminated through publications, conferences and colloquia. These activities are aimed to foster cooperation between the private sector and public administrations, as well as the exchange of ideas and initiatives.

The sponsors of the Public-Private Sector Research Center are the following:

- Ajuntament de Barcelona

- Departament d' Economia i Coneixement de la Generalitat de Catalunya

- Departament d' Empresa i Ocupació de la Generalitat de Catalunya

- Diputació de Barcelona

- EVERIS

- Fundació AGBAR

- Institut Català de les Empreses Culturals (ICEC)

- PricewaterhouseCoopers

- Sanofi

The contents of this publication reflect the conclusions and findings of the individual authors and not the opinions of the Center's sponsors. 


\title{
Budget procedures and fiscal performance: evidence from OECD countries in the wake of the crisis
}

\author{
Yulia Kasperskaya $^{1}$ \\ Ramon Xifré ${ }^{2}$
}

October 2016

\begin{abstract}
We analyze whether performance budgeting, budget transparency and medium-term expenditure frameworks are associated with the predicted moderation in the increase in the public debt-to-GDP ratio in OECD countries between 2008 and 2014. We find these countries naturally separate into two groups with different fiscal trajectories, but there is considerable heterogeneity within both groups in their use of the procedures. Notably, Belgium, Hungary and Norway present good fiscal trajectories but low levels of budget procedure use. Here, insights from political economy contribute little as the three countries fail to adhere to most of the rules deemed necessary for fiscal discipline. However, they present several common features: decentralized decision-making; distinct organizational climate governing budget administration; and, heavy reliance on agencies/public-private bodies. A standard package for enhancing fiscal performance does not therefore seem to exist, rather countries selectively adopt budget procedures to match their resources and institutions.
\end{abstract}

Keywords: budget procedures, fiscal performance, OECD

JEL codes: H11, H61, H63

\footnotetext{
1 Universitat de Barcelona, Departament d’Economía i Organització d’Empreses. yulia.kasperskaya@ub.edu

2 ESCI - Universitat Pompeu Fabra and Public-Private Sector Research Center, IESE Business School. ramon.xifre@esci.upf.edu
} 


\section{Introduction}

The 2008 financial crisis placed fiscal performance at the top of political, economic and social agendas worldwide. Indeed, according to the World Economic Forum (2105), fiscal crises rank second on its list of global economic risks in terms of their impact and third in terms of likelihood. In response to fiscal crises, governments have typically opted to increase revenues and cut spending, while recognizing that good fiscal performance requires a suitable fiscal framework and good governance. In this regard, this article studies the role that three budget procedures play in fiscal performance. Specifically, we examine whether performance budgeting, medium-term frameworks and budget transparency have been associated with better fiscal results in the OECD countries between 2008 and 2014.

We focus on these three budget procedures for the following reasons. First, they are the procedures of a rational decision-maker, used to support budgetary decisions on grounds of objective analysis and considerations of effectiveness, fiscal sustainability and transparency, and as such they avoid political subjectivity. Second, they form part of the canonical recommendations that supranational organizations regularly make to countries seeking to improve the functioning of their budget systems (European Commission, 2010; IMF, 2014; OECD, 2015a; Hearn and Phaup, 2016). It seems then pertinent to examine whether these procedures, in isolation of the rest of the fiscal framework, enhance fiscal discipline and public administration governance.

The reason for examining fiscal performance after 2008 is that the aftermath of the global crisis has revealed acute differences in the fiscal conditions of the OECD countries, which had previously remained more muted. It seems likely, therefore, that we now know more about countries' fundamental fiscal frameworks and behavior than we did before the crisis. 
Initially, we find no conclusive empirical evidence to determine the effectiveness of the procedures. We measure fiscal performance in terms of the variation in the public debtto-GDP ratio and we determine the level of usage of the budget procedures by constructing indicators from the OECD Budgeting Survey. Some of the countries with the best fiscal performance present relatively low scores in relation to the three budget procedures considered, while others in which the fiscal situation has deteriorated present high scores. More generally, we find that OECD countries separate into two groups along the fiscal dimension ("stable" debt and "exploding" debt countries), but that the budget procedure profiles of these two groups are not obviously distinct. This makes the establishment of a monotonic relationship between more developed/advanced budget procedures and better fiscal performance problematic.

The dynamics of the economic cycle clearly play an important role in a country's fiscal trajectory. For a given set of budget procedures and institutions, lower GDP growth results in higher debt. Indeed, for most countries in the "exploding" debt group, the variation in their debt-to-GDP ratio can largely be explained by their economic growth trajectory. However, even when analyzing the three variables simultaneously (i.e., fiscal performance, budget procedures and economic growth), the decoupling of budget procedures from fiscal performance persists for a number of countries, most notably Belgium, Hungary and Norway, three countries in the "stable" debt group that present some of the best fiscal trajectories. Yet, these countries have lower GDP growth rates and, more pertinently, present lower scores in terms of their use of the three budget procedures than their peer "stable" debt countries.

To address this puzzle, in the second part of the article, we review the most salient features of the budget process in these countries. Our hypothesis is that certain elements of their budget framework act as partial substitutes for the three budget procedures under investigation and we seek to identify them by conducting a qualitative analysis of the three budget administrations. We first examine the extent to which the fiscal administrations of the three countries employ the rules and mechanisms that the political economy literature suggests should enhance budget discipline. We find most of those elements to be absent.

We are then able to identify the three main dimensions in which the budget administration of these countries differs from that of the rest of the OECD countries: 
namely, the decision-making process; the organizational climate; and the role of publicprivate bodies and agencies in the provision of public services.

The article is structured as follows. Section 2 presents the three budget procedures analyzed and reviews the related literature. Section 3 describes the data and methodology used. In section 4, we analyze the fiscal trajectories of OECD countries between 2008 and 2014 and show their relation to economic growth and the implementation of the budget procedures. Here, we identify Belgium, Hungary and Norway as interesting cases for further study. Section 5 discusses what it is that makes the budget systems in these three counties distinctive. Finally, in section 6 draw our main conclusions.

\section{Background}

The belief that countries can enhance their fiscal performance by adopting certain types of budget rules or procedures is well established. The public administration and political economy literatures, albeit from different perspectives, have been especially active in testing this belief. Thus, while the former has focused its attention on understanding the mechanisms that account for the way in which a particular budget procedure improves public governance, the latter takes a more "systemic" approach and tends to be more interested in aggregates and on examining the implications for fiscal performance of the role and decisions of key policy makers and budget institutions. In this section, we review the main findings of both literatures as regards the three budget procedures considered here: namely, performance budgeting, medium-term expenditure frameworks and budget transparency mechanisms. As discussed, we opt to focus on these three procedures as they have come to represent canonical policy recommendations both in the US and the EU (European Commission 2010; Hearn and Phaup 2016).

The OECD broadly defines performance budgeting as a form of budgeting that "relates funds allocated to the measurable results" (OECD, 2007, p. 20). As such, the procedure implies the use of quantitative targets and their evaluation over the budget cycle. In some countries, such as Canada and France, the central budgeting authority (CBA) plays a leading role in imposing a standardized performance budgeting framework, while in other countries, such as Germany and Belgium, line ministries adopt their own ad hoc approaches. Performance budgeting is believed to enhance fiscal performance in 
two ways. First, it can help overcome political subjectivity in budgetary appropriations (Willoughby, 2011) and facilitate efficient allocation of resources, effective program management and adequate investment decisions (Joyce, 2007; Roberts, 2003). Second, performance information can be used by the legislature and by external government stakeholders to monitor and control policymaking (Bouckaert, 1996, p. 234; Pollitt and Bouckaert, 2011). Crain and O'Roark (2004) have shown that the introduction of performance-based budgeting has reduced spending per capita in the US states. All in all, in certain circumstances, the procedure should come hand-in-hand with the "right" type of flexibility, which is likely to help the government to adjust better to the economic cycle and so improve its fiscal trajectory (Robinson and Last, 2009).

The use of the medium-term expenditure framework (MTEF) constitutes a planning technique, which facilitates the consistency of public spending over time, and minimizes inefficient political distortions. Typically, MTEFs rely on macroeconomic and fiscal forecasts when making projections for the main budgetary allocations and establishing expenditure ceilings over periods of three to five years (OECD, 2013a). The OECD regards this technique as critical for ensuring fiscal discipline and, indeed, Vlaicu et al. (2014) reported that MTEFs improved budget balances in a panel of 180 countries. Hearn and Phaup (2016) argue that adding a long-term budget constraint may help overcome the short-term vision of politicians and policymakers and so facilitate budgetary planning.

Budget transparency mechanisms refer to how timely and fully budgets are disclosed to all interested parties, including politicians, citizens and think tanks. As regards best practice benchmarks, the OECD recommends governments provide comprehensive budget information, including pre-budget reports and other intermediate reports; details on specific disclosures, such as tax expenditures, financial liabilities and non-financial assets; explanations of their accounting policies along with details about responsible entities and ministers; and, audit reports (OECD, 2002). Budget transparency is considered essential for budget scrutiny and analysis and, therefore, for helping hold governments to account, and for controlling their spending policies. Such mechanisms should serve to limit the possibilities for politicians to act opportunistically, generating fiscal deficits and overspending (Alesina and Perroti, 1999). Alt and Lassen (2006) found that a higher degree of transparency is conducive to lower levels of public debt 
and deficits. In a similar vein, Benito and Bastida (2009) reported a positive relationship between government fiscal balances and the degree of budget transparency.

The political economy literature, in its concern for the relationship between budget procedures and fiscal performance, has focused on the idea that certain types of budget rules and regulations operating over the budget cycle may enhance a country's fiscal performance (Poterba and von Hagen, 1999; Hallerberg et al., 2009). The formal and informal rules and procedures (or budgetary institutions) include the negotiation, voting and amendment of rules of budget, numerical fiscal rules and the involvement of independent fiscal authorities (Ayuso-i-Casals et al., 2009). Empirical studies conducted in the 1980s and '90s showed that those countries which had (a) a strong finance minister, (b) a more centralized, or 'top-down', budgeting approach and (c) less fragmented legislature and executive displayed, on average, better fiscal outcomes (Alesina and Perroti, 1999). It was argued that a strong finance minister was able to impose limits on the budgets of individual ministries via bilateral negotiations, block excessive expenditure and resist political opportunism. In contrast, fragmented legislature and executive was more likely to lead to a large number of policymakers participating in the budget process seeking to obtain resources without fully internalizing their costs (Kontopolous and Perroti, 1999). Similarly, limits on the power of the legislature to amend the budget as well as restrictions on overspending, carrying over unspent funds and the transfers of expenditures between chapters were considered to be conducive to fiscal discipline (de Haan et al., 1999; Gleich, 2003).

Hallerberg and von Hagen (1999) stress the importance of the political system for budgeting and identify two types of budget approach: the delegation, and the contract (or commitment) approaches. The delegation approach employs top-down budget procedures, granting important decision rights to the finance minister (or the like), who has a prerogative over the spending ministries and the legislature as regards budget matters. This approach tends to be more effective in countries with majoritarian governments, or coalition governments that are ideologically homogeneous (Hallerberg et al., 2009). The contract/commitment approach implies that key policy makers define the budget in relation to the negotiated budget targets and in this way commit themselves to fiscal discipline. The approach resembles that of government micro-fiscal rules is best suited to multi-party coalition governments with diverse ideological agendas. In an analysis of EU countries before the crisis, Hodson (2009) concludes that 
any distinction between countries on these grounds is far from clear-cut, since some delegation states also employed budgeting fiscal rules. Some studies suggest that before the crisis EU countries employing the commitment approach performed better than did their delegation counterparts (Annet, 2006; Hallerberg, 2004).

However, while the mainstream view is that improving budget procedures has a positive fiscal impact, a number of caveats must be recognized. The objections are particularly substantial in the case of performance budgeting. Schick (2014) and Marcel (2014) find it difficult in practice to claim unambiguously that these practices have significant, positive effects and report that they are actually in decline in some countries. Hou et al. (2011) show that an effective performance management system takes time to develop and operate correctly and that it appears to function better for executive management than for legislative purposes.

\section{Variables and methodology}

\section{3.a Variables}

The majority of the budget procedure variables are taken from the OECD survey of budget practices and procedures conducted in $2012^{3}$. The OECD country responses were originally collected between November 2012 and February 2013 and verified in June 2013. The OECD has conducted extensive quality control of the responses in order to ensure consistency and reliability.

We focus on the following three dimensions of budget procedures: (A) performance budgeting; (B) the use of medium-term expenditure frameworks; and (C) budget transparency. All refer to central government procedures.

In relation to performance budgeting, we include the following indicators: (A1) performance budgeting index designed by the OECD; (A2) intensity of use of six types of performance information in negotiations with the central budget authority (CBA): financial data, operational data/performance reports, spending reviews, statistical information, independent information, and performance evaluations; (A3) overall consequences for poor performance, which includes three elements: public disclosure, intensified monitoring, and budget decreases.

\footnotetext{
${ }^{3}$ Data are available for 32 OECD countries (but not for Iceland or Israel).
} 
In the case of medium-term expenditure frameworks, we collected data from the medium-term perspective index designed by the OECD (B).

Finally, in relation to budget transparency we include the variable of total budgetary information made publicly available by the OECD (C), which comprises nine different types of budget-related information.

In table A.1 in the appendix we present the indicators collected and the transformations made in order to obtain summary budget procedure variables.

In the case of fiscal performance, we characterize a country's fiscal trajectory in terms of the variation in gross public debt as a percentage of GDP. This variable captures all liabilities that require payment by the sovereign state. It is the key stock variable that captures the state of public finances and is widely considered to be a comprehensive measure of fiscal performance (Alesina and Perotti, 1999; Ostry et al. 2015). Public debt is heavily influenced by GDP growth and so we also include this variable. In both cases, our data source is the IMF World Economic Outlook (WEO) database.

\section{3.b Methodology}

Our methodology comprises three steps. First, we separate countries into two groups according to their fiscal performance between 2008 and 2014. "Stable debt" OECD countries are those for whom the debt-to-GDP ratio increased at a rate below the OECD average for this period, while the "exploding debt" countries are those that present a rate above this average.

Second, within each group, we seek to identify the countries that do not conform to the group pattern when considering three variables simultaneously: namely, their fiscal performance, average GDP growth rate and normalized budget procedure scores. While our data on debt and GDP growth are one-dimensional, the data on budget procedures are multidimensional. This means we need to produce simple transformations of the budget procedure performance indicators, based on percentiles, so as to allow for aggregation. For a given budget procedure variable (A1, A2, A3, B and C), each country's score is normalized as the percentile in the respective distribution. Thus, we are able to compute an aggregate indicator of performance budgeting (A) as the average percentile of the three elements (A1, A2, and A3), and an aggregate indicator of the overall budget procedures as the average percentile of the three main variables $(\mathrm{A}, \mathrm{B}$, 
and C). In this way, we identify Belgium, Hungary and Norway as outliers within the "stable debt" group of countries.

Third, we conduct a qualitative analysis to identify the features that distinguish the budget systems of these three outliers from those of the rest of the OECD countries. This analysis draws on policy papers, archival data and a literature review.

\section{Fiscal trajectories and budget procedures in OECD countries}

\subsection{Fiscal trajectories: two groups}

Taking the OECD as a whole, the country-wide average public debt-to-GDP ratio rose from $52 \%$ in 2008 to $74 \%$ in 2014 . This average increase of 22 percentage points, however, masks two different trajectories among individual OECD countries (table 1).

[Table 1 here]

In 19 of the 32 OECD countries, the debt-to-GDP ratios increased less than the overall average and, moreover, their values remained relatively stable over the period, rising from 43.1 to $49.9 \%$ between 2008 and 2014. These 19 countries are, henceforth, referred to as the "stable debt" countries and are identified in table 2. In contrast, the ratio in the remaining 13 countries shifted from an average of 64.8 to $108.7 \%$ of GDP. These countries, henceforth, are referred to as the "exploding debt" countries and are identified in table 3.

The difference between the stable and exploding debt countries is of relevance in understanding why the dispersion (i.e. the standard deviation) of the debt-to-GDP ratio increased in this period. An initial inspection of the OECD countries suggests that they became more fiscally heterogeneous between these dates, as the standard deviation of the debt-to-GDP ratio rose from 36.7 to $49.8 \%$. However, here the aggregate statistic captures two very different patterns. Between 2008 and 2014, the standard deviation of the ratio in the stable debt group countries remained relatively constant and well below the values reported by the countries in the exploding debt group. Hence, most of the dispersion in the overall fiscal performance is attributable to the exploding debt countries ( 7.2 vs. just 2.3 points in the countries in the stable debt group). 
This analysis suggests that the crisis did not create a new fiscal divide among the OECD countries, rather it exacerbated existing, albeit muted, differences in the fiscal conditions between the two sets of countries.

The two groups of fiscally distinct countries also differ in terms of their respective GDP growth. When averaging across all countries within each group, stable debt countries grew at $1.3 \%$ per year between 2008 and 2014, while in the exploding debt countries GDP fell by an annual average of $0.2 \%$. As is well known, there is a negative association ${ }^{4}$ between GDP growth and public debt increases and this clearly holds in our sample as illustrated in figure $1 .^{5}$

[Figure 1 here]

\subsection{Budget procedures scores, fiscal outcomes and economic growth: individual cases}

However, inspection of the normalized budget procedure scores shows that both groups of countries present very similar averages. Indeed, they cannot be distinguished in terms of the overall budget procedure indicator ( 0.49 stable debt vs. 0.51 exploding debt), performance budgeting ( 0.48 vs. 0.45 , respectively) or medium-term framework (both present an average of 0.63 ). In the case of the budget transparency indicators, a minor difference is found ( 0.36 stable debt vs. 0.45 exploding debt).

The reason for this lies in the fact that both the stable and exploding debt groups of countries present significant variation across virtually all the budget procedure dimensions. We turn, therefore, to explore individual country behavior and the role that GDP growth plays in that.

Tables 2 and 3 report the economic variables and the normalized budget procedure variables for stable-debt and exploding-debt countries, respectively. The countries are sorted in increasing order in terms of the variation in their debt-to-GDP ratios.

[Table 2 here]

\footnotetext{
${ }^{4}$ The relationship between economic growth and the increase in public debt has been widely examined, particularly for its policy implications in post-2008 crisis management. Although it is difficult to draw direct, unidirectional causal relationships between the two variables, the negative association between both variables is well established (see Reinhart and Rogoff, 2010; Pescatori et al. 2012; and Panizza and Presbitero, 2014 for details).

${ }^{5}$ The correlation coefficient between the variation of debt-to-GDP ratio and the average real GDP growth for the period 2008-2014 is -0.62 (significant at the 0.01 confidence level for $\mathrm{N}=32$ ).
} 
[Table 3 here]

The political economy literature, which typically addresses this issue from a macroeconomic perspective, finds an association between good (bad) fiscal trajectory, relatively high (low) scores on budget procedure use, and high (low) average GDP growth. The basic logic here seems clear: high GDP growth improves public finances and this, in turn, is reinforced when countries employ sound budget procedures intensively.

In our analysis, some countries do conform to this norm. Among the group of stabledebt countries, Sweden, Mexico and Canada are the obvious examples. All three report low increases in their debt-to-GDP ratios, present a GDP growth rate above the specific group average, and record higher scores on budget procedures than the OECD average both on the aggregate budget indicator and on most of the specific budget procedure scores.

Likewise, among the group of exploding-debt countries, Italy, Spain and Greece are clear examples of the opposite occurring: high debt increases coupled with low growth and low budget procedure scores. Indeed, the negative correlation between the increase in public debt and the variation in GDP growth is much stronger for the exploding-debt countries than for their counterparts in the stable-debt group, where it is not significant ${ }^{6}$. This suggests that for this group of countries most of the variation in fiscal conditions can be explained by poor economic growth.

However, within the stable debt group, some countries do not conform to this norm. The most salient cases are Belgium, Hungary and Norway. The experiences in these countries run counter to the above logic. They recorded healthy fiscal trajectories between 2008 and 2014, but presented relatively low GDP growth figures and, more relevantly to our discussion, very low normalized budget procedure scores. In terms of aggregate budget procedure use (column 3 in tables 2 and 3) and specific performance budgeting (column 4), none of the three countries lies above the 30th percentile in the OECD distribution. In the case of budget transparency, they occupy even worse positions in the distribution, the most striking cases being Hungary and Norway whose

\footnotetext{
${ }^{6}$ The correlation between GDP variation and debt-to-GDP ratio variation in the period 2008-2014 is -0.64 for the exploding-debt countries (significant at 0.01 level for $\mathrm{N}=13$ ) and -0.23 for the stable-debt countries (not significant for $\mathrm{N}=19$ ).
} 
percentiles are 12 and 6, respectively. Similarly, in terms of economic growth, none of the three has grown by more than $0.9 \%$ on average during the period, well below the average for the stable-debt countries $(1.3 \%)$. Yet, in contrast to these figures, the three countries were among the OECD's best fiscal performers.

\section{Distinctive budget attributes of Belgium, Hungary and Norway}

The results presented by these three countries suggest that other factors in the fiscal and budgetary frameworks (and omitted from the preceding analysis) are relevant for fiscal performance. We hypothesize that some elements of the budget framework, and more generally of the fiscal framework, may therefore be acting as partial substitutes. Thus, what matters for a country's fiscal performance is not the presence (or otherwise) of a particular fiscal institution or the application of a certain budget procedure nominally and in isolation, but rather the functioning of the whole budget system. From this perspective, the budget system is constructed from a complex set of relationships of substitutability and complementarity between procedures and institutions. This would explain why a country not making great use of (one or more of) the three budget procedures can overcome this apparent shortcoming by relying more intensively on other elements of its fiscal framework.

This hypothesis is in line with Pollitt and Bouckaert (2011), who coin the term 'menu approach' to describe how some governments choose a package of administrative reforms influenced by the prevailing administrative culture, state structure and economic background. More specifically, a similar theoretical approach based on relationships of complementarity and substitutability has been adopted by various articles analyzing budget systems. For example, in their study of the US states, Hou and Brewer (2010) find that two particular instruments for budget stabilization, namely, general fund balances and budget stabilization funds, are partial substitutes. That is, the influence of one instrument is partially offset by that of the other. From a somewhat more broad perspective, in an examination of the relationship between open elections, accountability, and budgetary institutions, $\mathrm{Ma}$ and Hou (2009) reveal a strict complementarity relationship. They show that electoral accountability is no guarantee of overall government accountability if proper budgetary institutions are not in place. Likewise, in a study of how best to manage budget slack, Rose and Smith (2012) find that two actual practices, namely, setting surpluses aside and concealing budget slack, 
operate as substitutes, whereby doing more of the one is associated with doing less of the other.

We test our hypothesis qualitatively in two stages. First, we examine whether the insights from the political-economy literature can help account for the apparent anomalies presented by Belgium, Hungary and Norway. Can the variables considered in this literature explain why these three countries presented a healthy fiscal performance despite the fact that their economic growth was weak and they made little use of the budget procedures? Second, we seek to identify any distinctive elements in the budget systems and fiscal frameworks of these three countries vis-à-vis those of the rest of the OECD countries. What is it that makes their budgeting different? ${ }^{7}$

We summarize our findings in table 4 , which includes three groups of variables. The first corresponds to general information about each country, including state type (unitary of federal) and a measure of fiscal decentralization. The second reports key variables for the political economy literature, including the power of the legislative vs. the executive, government structure and approach to fiscal governance (contract vs. delegation). Finally, the third seeks to highlight the distinctive features of their budget systems.

[Table 4 here]

\section{General background indicators}

In all three countries the taxing power of the sub-central governments is below that of the OECD average and, therefore, central government plays a relatively important role in budgeting. This rules out fiscal decentralization as a potential explanation for their low level of usage of the budget procedures by central governments.

Two of the three are unitary states, while Belgium is a federal state, while two form part of an economic union and Norway does not. Thus, it is not easy to associate the source of their differential budget behavior with a particular profile with regard to these two characteristics.

\footnotetext{
${ }^{7}$ See the note in table 4 for the sources of this qualitative analysis.
} 


\section{Political economy indicators}

Between 2008 and 20014, Belgium and Norway had coalition governments and, in line with predictions (Hallerberg and von Hagen, 1999), the fiscal governance model in both countries approximated more closely to that of the contract approach. In the case of Hungary, fiscal governance was more mixed in approach. On the one hand, the existence of a government majority can favor delegation; but, on the other, the role of the finance minister might not be sufficiently strong.

In all three countries, the legislature has virtually unlimited powers at all stages of the budget process vis-à-vis the executive. Their parliaments have unrestricted powers to amend the budget and the executive cannot veto the budgets once passed by the legislature. Likewise, their respective central budget authorities (CBA) have no final word in the resolution of budget disputes; they are not entitled to undertake performance evaluations or to make independent decisions with material impact on spending ministries. In two of the three cases (Hungary and Norway), the CBA is not an arm'slength institution, but a unit within the ministry of finance, with responsibility for preparing macroeconomic projections and fiscal scenarios.

As such, the institutional setups for budgeting in these countries lack most of the elements that have been identified in the political economy literature as necessary for achieving fiscal discipline (Hallerberg and von Hagen, 1999; Haan et al., 1999; Gleich, 2003). Moreover, in terms fiscal rules, what distinguishes Belgium and Hungary from the rest of the OECD countries is that they are among the few that have granted fiscal rules the highest legal status by incorporating them in their national constitutions. However, having said that, some countries that have experienced major fiscal crises, including Spain and Italy, have also incorporated the fiscal rules in their constitutions.

\section{Analysis of the distinctive features of the budget systems}

The budget systems of the three can be distinguished from those of the other OECD countries in terms of the following characteristics:

a. Decentralized budgetary decision-making. Belgium and Norway differ from the rest of the OECD countries as regards the significant degree of decentralization in their systems, albeit that the two also present their own quite distinctive traits. In Belgium, the CBA or Federal Public Service Budget is in charge of drafting the budget circular, 
preparing the proposal, defining and negotiating budgets with the spending ministries and preparing all reports (OECD, 2012). In addition, three independent institutions have certain responsibilities for the budget: the National Accounts Institute (NAI) covers the positive side of the budgetary process; the High Council of Finance deals with the normative side; and the Federal Planning Bureau produces, on behalf of the NAI, the macroeconomic forecasts (Bogaert et al. 2006). It seems undeniable that these entities contributed to the sustainability of Belgian public finances by producing accurate and politically independent macroeconomic projections which served as initial input for budget forecasts (Lebrun, 2009).

Norway's institutional setup, on the other hand, differs from that of most OECD countries in terms of the little power entrusted in the ministry of finance during budget negotiations. The minister does not negotiate budget proposals with ministries and agencies and there are no spending reviews that allow the minister to propose mediumterm reforms. Instead, expenditure negotiations tend to be decentralized and bilateral involving the expenditure center (ministries and agencies) and government or even parliament (Anderson et al., 2006).

In Hungary, budget governance is more centralized and the functions of its CBA are wider. Following recommendations from the European Commission, in 2009, Hungary established a Fiscal Policy Council with the powers to conduct independent macroeconomic forecasts and to review all legislative proposals and bills. However, the Council's role was significantly reduced in 2011 and its independence from the government has been called into question (Kopitz, 2011).

b. Organizational climate of budget administration. Budget administration in each of the three countries appears to be based on distinctive organizational principles to those applied in the rest of the OECD countries. One of the most salient features of Belgium's fiscal administration is its very high degree of transparency, exceeding in various respects international standards (IMF, 2008). It seems probable that this climate of transparency is associated with its model of governance, whereby fiscal responsibilities are shared and separated between three independent institutions, thus generating a system of checks-and-balances. One of the main features of Hungary's fiscal administration (and, for that matter, its public administration in general) is its drive towards increasing professionalism following a period of post-Soviet transition. 
Neshkova and Kostadinova (2012) describe Hungary as a front-runner in the adoption of administrative reform among post-Soviet countries, while Gadjuschek (2007) reports that the reform of the public sector has led to the professionalization of the civil service, attracting some of the country's most highly educated individuals. One of the most salient features of Norway's organizational climate is the high degree of trust and flexibility among all parties involved in the budget process (cabinet, line ministries and many agencies). Anderson et al. (2006) claim that this is the result of a unique set of contextual factors which appear to work successfully in Norway, such as the fact that the ministry of finance has chosen not to adopt a controlling role combined with the virtual absence of any formal controls.

c. The role of agencies. "Agencification", that is, the transfer of government activities to bodies outside ministerial departments, has many explanations (organizational, functional and institutional) and is a central element of reform in the New Public Management paradigm (Trondal, 2014). Its underlying principle is that the relationship between ministries and agencies has shifted and is now based more on the ex post control of results than on ex ante supervision requirements (Evrard and Scutnaire, 2006).

Of the three, agencification has advanced most in Belgium and Norway. Belgium's public administration is characterized by high levels of decentralization and functional devolution, particularly in the area of social security, which comprises 15 semi-public institutions. These institutions are subject to the supervisory authority of the responsible ministry and, in the case of decisions impacting the budget, to the budget minister; however, they enjoy a significant degree of autonomy (Evrard and Scutnaire, 2006). Norway can be distinguished from the rest of the OECD countries in terms not only of the high degree of managerial flexibility it grants its agencies but also of the significant scope the latter are afforded to organize the action of the public sector - which is perhaps a common feature of the Nordic countries. As Anderson et al. (2006) report, Norway has 17 small ministries and 180 agencies implementing public policies and $97 \%$ of government employees work for these agencies. The latter vary in size but they enjoy a reasonable degree of managerial flexibility and autonomy, although each is under the formal control of a ministry, which uses a letter of instruction to implement the agency's budget. 
d. Idiosyncratic factors. It is perhaps necessary to include a last category of country specific factors - exogenous to the budget process, but with a significant impact in fiscal terms. Although we might find instances of such factors in each of the three countries, none compares to the fiscal proceeds originating from Norway's oil reserves, proceeds that have been managed with great prudence. ${ }^{8}$

\section{Conclusions}

This article has examined whether and under which conditions three budget procedures (performance budgeting, medium-term frameworks and budget transparency) were associated with the variation in the debt-to-GDP ratio in the OECD countries between 2008 and 2014. A natural distinction emerged between countries presenting a stable debt vs. an exploding debt trajectory. Yet, this clear differentiation in fiscal terms is not observed in terms of budget procedures adopted, there being considerable heterogeneity within the two groups in their use of the three procedures.

Specifically, Belgium, Hungary and Norway differ from the other stable-debt countries in that their healthy fiscal trajectory is associated with comparatively little use of the three budget procedures. This, coupled with the fact that their economic growth was below that of the stable-debt group mean, indicating that growth rates do not account for their good fiscal performance, makes these three countries interesting case studies. We, therefore, examined whether these countries compensate for the limitations in their use of the three budget procedures by depending more heavily on other fiscal/budgetary institutions.

A review of the insights offered by the political economy literature showed that most of the elements recognized as encouraging good fiscal governance (the importance of centralized budget procedures, a strong finance minister, restricted rights of legislature and strict oversight over the spending ministries) are absent in these countries. We, therefore, sought to identify which dimensions of their budget systems differed from those of the rest of the OECD countries. This revealed that (i) their model of budgetary governance is relatively decentralized (Belgium and Norway); (ii) each country appears to have a distinctive organizational climate governing its budget administration and its

\footnotetext{
${ }^{8}$ According to the most recent analysis (IMF, 2015), petroleum-related revenue for the public sector has increased from an average of $7 \%$ of total revenue in the period 1971-1996 to $25 \%$ by mid-2000.
} 
public services in general (Belgium, Hungary and Norway); and (iii) government action tends to rely heavily on the work of semi-public agencies (Belgium and Norway).

Belgium's recipe for fiscal stability appears to be based on sharing budget powers and functions among independent bodies. It has established a system of checks and balances that is entirely positive for its public finances. Norway exemplifies a country with a highly decentralized budget governance, with a broad pattern of delegation to agencies. However, it demonstrates a firm commitment to balancing its domestic budget (helped in this endeavor by the proceeds from oil). Hungary emerges as a front-runner in postSoviet reform, in which the civil service has attracted much of the country's talent, generating a highly professional atmosphere in public sector management.

In short, our findings suggest that a standard package of budget procedures capable of safeguarding a country's fiscal performance does not exist; rather, countries selectively adopt the budget procedures to match their resources and institutions. Our findings also strongly suggest that budget systems are constructed from a complex set of relationships of complementarity and substitutability among procedures and institutions.

Future research is needed to address in greater detail how countries go about choosing their optimal budget procedure packages and to understand the conditions under which they can enhance their fiscal performance. In this respect, additional budget procedures apart from the three studied in this work could be examined. 


\section{References}

Alesina, A., R. Perotti, 1999. "Budget Deficits and Budget Institutions", NBER Chapters, in: Fiscal Institutions and Fiscal Performance, pages 13-36 National Bureau of Economic Research.

Alt J. E. and D. D. Lassen (2006). Fiscal transparency, political parties, and debt in OECD countries. European Economic Review, 50, 1403-1439.

Anderson, B., T. Curristine, O. Merk (2006). Budgeting in Norway. OECD Journal on Budgeting, vol. 6, no. 1.

Anderson, B. (2010). A Summary of the OECD Review of Budgeting in Mexico. Mimeo.

Annet, A. (2006) Enforcement and the Stability and Growth Pact: How Fiscal Policy Did and Did Not Change Under Europe's Fiscal Framework, IMF working paper WP/06/116.

Ayuso-i-Casals, J., Deroose, S. , Flores, E. and Moulin, L. (2009) Introduction: The Role of Fiscal Rules and Institutions in Shaping Budgetary Outcomes in Policy Instruments for Sound Fiscal Policies ed. by Ayuso-i-Casals, J., Deroose, S. , Flores, E. and Moulin, L., pp.1-20 London: Palgrave Macmillan

Benito, B. and F. Bastida (2009). Budget transparency, fiscal performance and political turnout. Public Administration Review. May, June 2009.

Bouckaert, G. (1996) Improving Performance Measurement, in A. Halachmi and G. Bouckaert (eds.) Organizational Performance and Measurement in the Public Sector. London: Quorum Books

Bogaert, H., L. Dobbelaere, B. Hertveldt, I. Lebrun (2006). Fiscal Councils, independent forecasts and the budgetary process: lessons from the Belgian case. Federal Planning Bureau, Working Paper 4-06.

Crain, W. M. and J. B. O'Roark (2004). The impact of performance-based budgeting on state fiscal performance. Economics of Governance. 5: 167-186.

Christiaens, J. R. (2003). Accrual accounting reforms in Belgian Local Governments: A comparative Examination. Journal of Public Budgeting, Accounting \& Financial Management, 15(1), 92-109.

Dabla-Norris, E., Allen, R., Zanna, L-F., Prakash, T., Kvintradze, E., Lledo, V., Yakovlev, I. and S. Gollwitzer (2010) Budget Institutions and fiscal performance in low-income countries. IMF WP/10/80

European Commission (2010). Public Finances in the EMU 2010. DG ECFIN. 
Evrard, M. and P. Scutnaire (2006). The "Control" of Public Social Security Institutions in Belgium. OECD Journal on Budgeting, vol. 5, no. 3

Gajduschek, G. (2007). Politization, Professionalization, or Both? Hungary's Civil Service System. Communist and Post-Communist Studies 40(3); 343-62

Gleich, H. (2003) Budget institutions and fiscal performance in Central and Eastern European Countries. European Central Bank Working Paper no. 215.

de Haan, J., W. Moessen and B. Volkerink (1999). Budgetary procedures - Aspects and Changes: New Evidence for Some European Countries", in J. Poterba and J. von Hagen (eds.) Fiscal Institutions and Fiscal Performance. Chicago University Press.

Hallerberg, M. and J. von Hagen (1999) Electoral Institutions, Cabinet Negotiations and Budget Deficits within the European Union in Fiscal Institutions and Fiscal Performance, Chicago, IL: University of Chicago Press, pp. 209-232

Hallerberg, M. (2004) Institutions and Fiscal Performance. Domestic Budgets in a United Europe: Fiscal Governance from the End of Bretton Woods to EMU, Ithaca: NY: Cornell University Press.

Hallerberg, M., R. Strauch and J. v. Hagen (2009). The design of fiscal rules and forms of governance in European Union Countries in Policy instruments for Sound Fiscal Policies. Fiscal Rules and Institutions ed.

Hawkesworth, I. and Klepsvik, K. (2013) Budgeting levers, strategic agility and the use of performance budgeting in 2011/12, OECD Journal on Budgeting, Vol.13, N 5, pp. 105-140.

Hearn, James J. and M. Phaup (2016). "Federal Budget Reform: A Behaviorally Informed Approach", Working Paper \#4 in the George Mason University Series for the National Budgeting Roundtable.

Hodson, D. National Fiscal Institutions and the Stability and Growth Pact: Are 'Delegation' States at a Disadvantage? in Policy Instruments for Sound Fiscal Policies ed. by Ayuso-i-Casals, J., Deroose, S. , Flores, E. and Moulin, L., pp.149-172 London: Palgrave Macmillan.

Hou, Y. R. S. Lunsford, K. C. Sides and K. A. Jones (2011). State Performance-Based Budgeting in Boom and Bust Years: An Analytical Framework and Survey of the States. Public Administration Review, vol. 71.3, pp. 370 - 388.

Hou, Y., G. A. Brewer (2010). Substitution and Supplementation Between CoFunctional Policy Instruments: Evidence from State Budget Stabilization Practices. Public Administration Review, vol. 70.6, pp. 914 - 924.

IMF (2008). Belgium: Report on the Observance of Standards and Codes - Fiscal Transparency Module. IMF Country Report 08/116. 
IMF (2014) Fiscal Forecasting and Budgeting in Fiscal Transparency Code

IMF (2015). Norway. Selected Issues. IMF Country Report No. 15/250.

Joyce, P.G. (2007) Performance and Budgeting under the Separation of Powers in Performance Budgeting: Linking Funding and Results, ed. By Robinson M., International Monetary Fund, pp.442-461

Joyce, P. G. (2011). The Obama Administration and PBB: Building on the Legacy of Federal Performance-Informed Budgeting? Public Administration Review, vol. 71.3, pp. $356-367$.

Kontopolous, Y. and Perotti, R. (2009) Government fragmentation and Fiscal Policy Oucomes: Evidence from OECD countries in Fiscal Institutions and Fiscal Performance, pages 81-101 National Bureau of Economic Research.

Kopitz, G. (2011). Independent Fiscal Institutions: Developing Good Practices, OECD Journal on Budgeting, Vol. 11/3

Kraan, D.J., D. Bergvall, I. Hawkesworth and P. Krause (2007). Budgeting in Hungary. OECD Journal on Budgeting, vol. 6, no. 3

Lebrun, I. (2009) Fiscal Councils, Independent forecasts and the Budgetary Process: Lessons from the Belgian Case in Policy Instruments for Sound Fiscal Policies ed. by Ayuso-i-Casals, J., Deroose, S., Flores, E. and Moulin, L., pp.1-20 London: Palgrave Macmillan

LeLoup, L. T. (2000). Parliamentary Budgeting in Hungary and Slovenia. Mimeo. American Society for Public Administration Annual Meeting.

Ma, J. and Y. Hou (2009). Budgeting for Accountability: A Comparative Study of Budget Reforms in the United States during the Progressive Era and in Contemporary China. Public Administration Review, 69:1, S53-S59.

Marcel, M. (2014). Budgeting for fiscal space and government performance beyond the great recession, OECD Journal of Budgeting, Vol.2013/2.

Neshkova, M. I. and T. Kostadinova (2012). The Effectiveness of Administrative Reform in New Democracies. Public Administration Review, vol. 72.3, 324-333.

OECD (2002) OECD best practices for budget transparency, OECD Journal of Budgeting.

OECD (2007) Performance Budgeting in OECD countries, OECD 2007

OECD (2012) International Budget Practices and Procedures Database, accessible at http://qdd.oecd.org/subject.aspx?Subject=7F309CE7-61D3-4423-A9E3-

3F39424B8BCA 
OECD (2013a) "Executive budget flexibility" in Government at a Glance 2013. OECD Publishing

OECD (2013b) "Medium-term expenditure frameworks" in Government at a Glance 2013. OECD Publishing

OECD, 2014 Budgeting Practices and Procedures in OECD countries.

OECD (2015b). Government at a Glance 2015.

OECD (2015a) Recommendation of the Council on Budgetary Governance, Public Governance \& Territorial Development Directorate.

Ostry, J. D., A. R. Ghosh, R. Espinoza (2015). "When Should Public Debt Be Reduced?", IMF Staff Discussion Note, SDN 15/10.

Olden, B., D. Last, S. Yläoutinen, C. Sateriale (2012) Fiscal consolidation in Southeastern European Countries: The Role of Budget Institutions. IMF Working Paper $12 / 13$.

Panizza, U., and A. F. Presbitero (2014). Public debt and economic growth: is there a causal effect?. Journal of Macroeconomics, vol. 41, pp. 21-41.

Pescatori, A., D. Sandri, and J. Simon. Debt and Growth: Is There a Magic Threshold?. IMF Working Paper 14/34.

Pollitt, C. and G. Bouckaert (2011) Many houses: types of politico-administrative regime in Public Management Reform: A comparative analysis-new public management, governance, and the Neo-Weberian state, Oxford University Press

Poterba, J.M and von Hagen, J. (1999) Introduction in Fiscal Institutions and Fiscal Performance, pp. 1-12, National Bureau of Economic Research

Reinhart, C. M and K. S. Rogoff (2010), Growth in a Time of Debt, American Economic Review: Papers and Proceedings, 100(2):573-578.

Roberts, J 2003 Managing Public Expenditure for Development Results and Poverty Reduction Working Paper 203, ISBN 085003647 Xess, pp. 47-75.

Robinson, M. and D. Last (2009). A Basic Model of Performance-Based Budgeting. IMF, Fiscal Affairs Department.

Rose, S. and D. L. Smith (2011). Budget Slack, Institutions and Transparency. Public Administration Review, 72.2, 187-195.

Schick, A. (2014) The metamorphoses of performance budgeting, OECD Budgeting Journal, Vol.13-N8, pp 49-79.

Trondal, J. (2014). Agencification. Public Administration Review, vol. 74.4, 545-549. 
Vlaicu, R., Verhoeven, M., Grigoli, F. and Z. Mills (2014) Multiyear budgets and fiscal performance: panel data evidence, Journal of Public Economics, 111, pp. 79-95

Willoughby, K. (2011) Introduction to the Symposium: PBB-Works Like the BCS? Public Administration Review 05/2011; 71(3):352 - 355.

World Economic Forum (2015). Global Risk Report 2015. 
Table 1. Gross debt as percentage of GDP. Descriptive statistics by groups of OECD countries.

\begin{tabular}{|l|c|c|c|c|c|}
\hline & & \multicolumn{2}{|c|}{2014} & \multicolumn{2}{|c|}{2008} \\
\hline & Count & Mean & $\begin{array}{l}\text { Standard } \\
\text { Deviation }\end{array}$ & Mean & $\begin{array}{c}\text { Standard } \\
\text { Deviation }\end{array}$ \\
\hline All OECD countries & 32 & 73.8 & 49.4 & 51.9 & 36.7 \\
\hline $\begin{array}{l}\text { "Stable Debt" countries } \\
\text { OECD countries with debt } \\
\text { variation lower than 22 p.p. } \\
\text { in 2008-2014 }\end{array}$ & 19 & 49.9 & 26.1 & 43.1 & 23.8 \\
\hline $\begin{array}{l}\text { "Exploding Debt" } \\
\text { countries } \\
\text { OECD countries with debt } \\
\text { variation higher than 22 p.p. } \\
\text { in 2008-2014 }\end{array}$ & 13 & 108.7 & 55.4 & 64.8 & 48.2 \\
\hline
\end{tabular}

Source. Based on IMF. 
Table 2. Economic and normalized budget variables for 'stable-debt' OECD countries.

\begin{tabular}{|c|c|c|c|c|c|c|}
\hline & \multicolumn{2}{|c|}{ Economic Variables } & \multicolumn{4}{|c|}{ Budget procedures, (average) percentiles } \\
\hline & $\begin{array}{l}\text { Debt/GDP } \\
\text { variation } \\
2008-2014\end{array}$ & $\begin{array}{l}\text { Average } \\
\text { GDP } \\
\text { growth rate } \\
2008-2014 \\
\end{array}$ & All $(A, B, C)$ & $\begin{array}{l}\text { A. } \\
\text { Performanc } \\
\text { e Budgeting } \\
\text { (A1, A2, A3) }\end{array}$ & $\begin{array}{l}\text { B. Medium- } \\
\text { term } \\
\text { Framework }\end{array}$ & $\begin{array}{l}\text { C. Budget } \\
\text { Transparenc } \\
\text { y }\end{array}$ \\
\hline Norway & -17.6 & 0.87 & 0.29 & 0.28 & 0.54 & 0.06 \\
\hline Turkey & -6.5 & 3.27 & 0.51 & 0.55 & 0.73 & 0.24 \\
\hline Switzerland & -2.6 & 1.42 & 0.57 & 0.68 & 0.78 & 0.24 \\
\hline Poland & 1.8 & 3.11 & 0.41 & 0.18 & 0.82 & 0.24 \\
\hline Sweden & 4.8 & 0.86 & 0.78 & 0.68 & 0.82 & 0.85 \\
\hline Hungary & 5.0 & 0.09 & 0.11 & 0.22 & 0.00 & 0.12 \\
\hline Estonia & 5.2 & -0.14 & 0.47 & 0.39 & 0.78 & 0.24 \\
\hline Mexico & 7.3 & 1.91 & 0.58 & 0.94 & 0.56 & 0.24 \\
\hline Korea & 7.7 & 3.19 & 0.60 & 0.85 & 0.83 & 0.12 \\
\hline Germany & 8.2 & 0.74 & 0.59 & 0.33 & 0.81 & 0.64 \\
\hline Chile & 9.0 & 3.62 & 0.43 & 0.61 & 0.43 & 0.24 \\
\hline Denmark & 9.2 & -0.45 & 0.52 & 0.60 & 0.90 & 0.06 \\
\hline Luxembourg & 10.2 & 1.09 & 0.40 & 0.34 & 0.00 & 0.85 \\
\hline Belgium & 13.4 & 0.56 & 0.18 & 0.29 & 0.00 & 0.24 \\
\hline Netherlands & 13.6 & 0.01 & 0.75 & 0.69 & 0.92 & 0.64 \\
\hline Czech Republic & 14.1 & 0.38 & 0.36 & 0.06 & 0.78 & 0.24 \\
\hline New Zealand & 14.1 & 1.33 & 0.63 & 0.54 & 0.73 & 0.64 \\
\hline Canada & 15.7 & 1.61 & 0.67 & 0.73 & 0.64 & 0.64 \\
\hline Austria & 18.3 & 0.59 & 0.38 & 0.08 & 0.81 & 0.24 \\
\hline Group average & 6.89 & 1.27 & 0.49 & 0.48 & 0.63 & 0.36 \\
\hline OECD average & 21.9 & 0.68 & 0.49 & 0.46 & 0.63 & 0.39 \\
\hline
\end{tabular}

Source. Based on IMF. 
Table 3. Economic and normalized budget variables for 'exploding debt' OECD countries.

\begin{tabular}{|c|c|c|c|c|c|c|}
\hline & \multicolumn{2}{|c|}{ Economic Variables } & \multicolumn{4}{|c|}{ Budget procedures, (average) percentiles } \\
\hline & $\begin{array}{l}\text { Debt/GDP } \\
\text { variation } \\
\text { 2008-2014 }\end{array}$ & $\begin{array}{l}\text { Average } \\
\text { GDP } \\
\text { growth rate } \\
2008-2014\end{array}$ & All $(A, B, C)$ & $\begin{array}{l}\text { A. } \\
\text { Performanc } \\
\text { e Budgeting } \\
\text { (A1, A2, A3) }\end{array}$ & $\begin{array}{l}\text { B. Medium- } \\
\text { term } \\
\text { Framework }\end{array}$ & $\begin{array}{l}\text { C. Budget } \\
\text { Transparenc } \\
y\end{array}$ \\
\hline Australia & 22.5 & 2.51 & 0.48 & 0.62 & 0.59 & 0.24 \\
\hline Slovak Republic & 25.8 & 1.88 & 0.42 & 0.68 & 0.46 & 0.12 \\
\hline Finland & 27.1 & -0.69 & 0.48 & 0.58 & 0.61 & 0.24 \\
\hline France & 27.3 & 0.33 & 0.80 & 0.55 & 0.88 & 0.97 \\
\hline Italy & 29.8 & -1.30 & 0.34 & 0.22 & 0.57 & 0.24 \\
\hline United States & 31.9 & 1.14 & 0.46 & 0.14 & 0.62 & 0.64 \\
\hline United Kingdom & 37.8 & 0.54 & 0.70 & 0.70 & 0.76 & 0.64 \\
\hline Japan & 54.6 & 0.13 & 0.62 & 0.45 & 0.57 & 0.85 \\
\hline Spain & 58.3 & -0.71 & 0.29 & 0.09 & 0.65 & 0.12 \\
\hline Portugal & 58.5 & -1.06 & 0.50 & 0.08 & 0.77 & 0.64 \\
\hline Slovenia & 61.3 & -0.52 & 0.49 & 0.61 & 0.61 & 0.24 \\
\hline Ireland & 66.9 & -0.26 & 0.62 & 0.56 & 0.46 & 0.85 \\
\hline Greece & 68.4 & -4.12 & 0.39 & 0.51 & 0.62 & 0.03 \\
\hline Group average & 43.9 & -0.17 & 0.51 & 0.45 & 0.63 & 0.45 \\
\hline OECD average & 21.9 & 0.68 & 0.49 & 0.46 & 0.63 & 0.39 \\
\hline
\end{tabular}

Source. Based on IMF. 
Figure 1. Real GDP growth (average 2008-2014) and variation in gross debt as percentage of GDP. Percentage points.

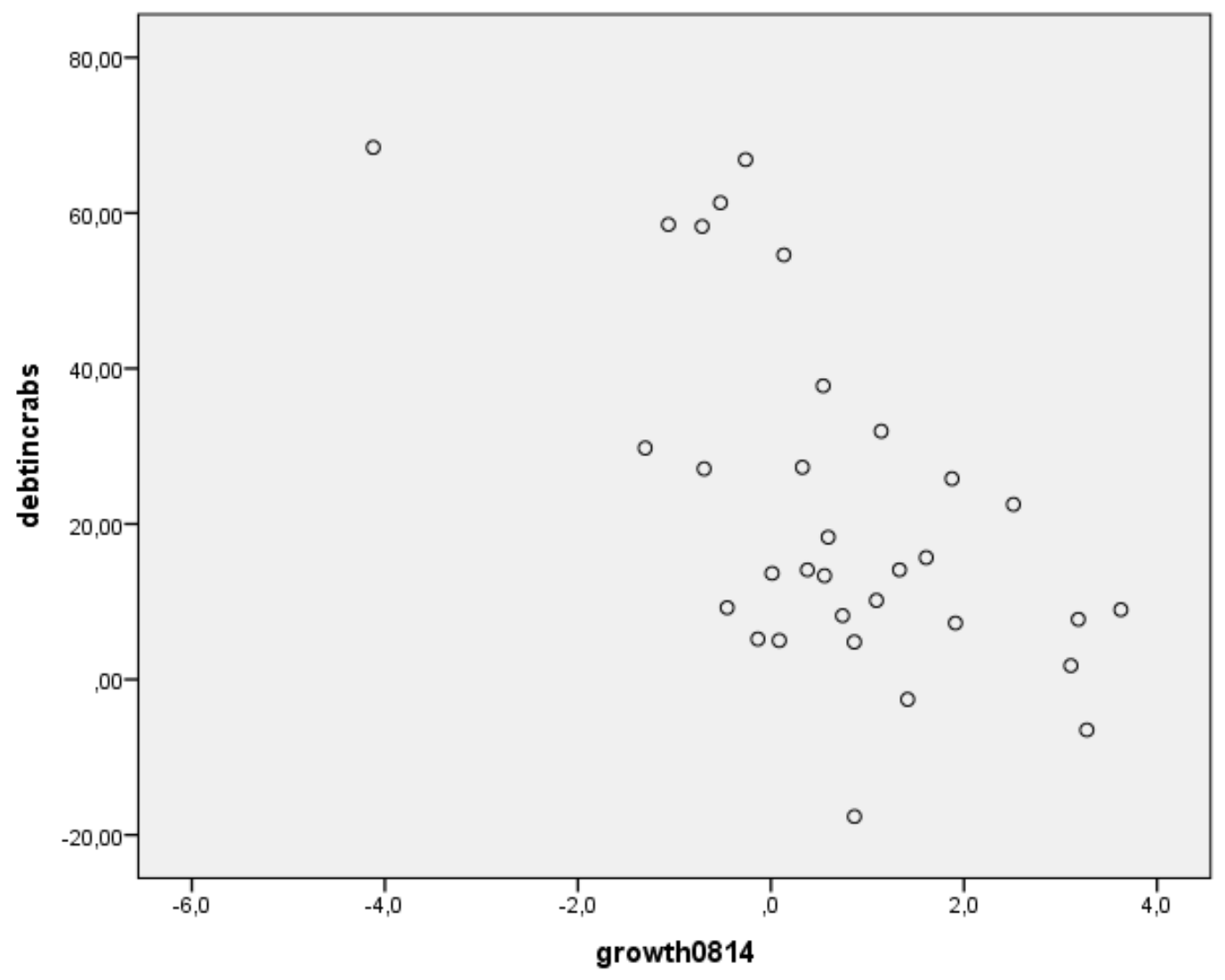

Source. IMF. 


\section{Appendix 1. Variables: description and measurement}

Budget Procedure Variables (source OECD, 2012, Survey on Budgeting Practices and Procedures/downloaded at Government at a Glance (2013)

\section{A. Performance Budgeting Indicators}

A1 Performance budget index. This composite index contains 11 variables that cover information on the availability and type of performance information developed, processes for monitoring and reporting on results and whether (and how) performance information is used on budget negotiations and decision-making by the central budget authorities, line ministries and politicians. The weightings are as follows: existence of performance information (65\%), use of performance information in budget negotiations $(20 \%)$ and consequences of not achieving the targets $(15 \%)$.

From 0 to 1 . Index elaborated by OECD

A2.1 Use of performance information (financial data) in negotiations with Central Budget Authority

( $0=$ Never; $1=$ Rarely; $2=$ Occasionally: $3=$ Usually and $4=$ Always)

A2.2 Use of performance information (operational data and performance reports) in negotiations with Central Budget Authority

( $0=$ Never; $1=$ Rarely; 2=Occasionally: $3=$ Usually and 4=Always)

A2.3 Use of performance information (spending reviews) in negotiations with Central Budget Authority

( $0=$ Never; $1=$ Rarely; $2=$ Occasionally: $3=$ Usually and $4=$ Always)

A2.4 Use of performance information (statistical information) in negotiations with Central Budget Authority

( $0=$ Never; $1=$ Rarely; $2=$ Occasionally: $3=$ Usually and $4=$ =Always)

A2.5 Use of performance information (independent performance information) in negotiations with Central Budget Authority

(0=Never; $1=$ Rarely; 2=Occasionally: $3=$ Usually and 4=Always)

A2.6 Use of performance information (performance evaluations) in negotiations with Central Budget Authority

( $0=$ Never; $1=$ Rarely; $2=$ Occasionally: $3=$ Usually and 4=Always)

A2 Total use of performance information in negotiations with Central Budget Authority

Sum of the variables of $A 3.1$ to $A 3.5(0,24)$ - our elaboration on the basis of OECD indicators

A3.1 Consequences for poor performance: organizational or programme's poor performance made public

(0=Never; $1=$ Rarely; 2=Occasionally: 3=Usually and 4=Always)

A3.2 Consequences for poor performance: intensified monitoring of organization and/or programme

(0=Never; $1=$ Rarely; $2=$ Occasionally: $3=$ Usually and 4=Always) 
A3.3 Consequences for poor performance: budget decreases

(0=Never; $1=$ Rarely; 2=Occasionally: 3=Usually and 4=Always)

A3 Total consequences for poor performance

Sum of the variables of $A 4.1$ to $A 4.3(0,12)$ - own elaboration

\section{B. Medium-term perspective}

B Use of a medium-term expenditure perspective in the budget process

The weightings are as follows: existence of a MTEF (25\%); length, levels and substance of the ceilings (33.3\%); quality and durability of the ceiling (25\%) and monitoring of the MTEF (16.67\%).

From 0 to 1. index elaborated by OECD

\section{Budget transparency indicators}

\section{Total budgetary information made publicly available}

Includes the responses about the following types of budgetary information: medium-term fiscal policies objectives (1), budget proposal (2), approved budget (3), methodology and economic assumptions for establishing fiscal projections (4), sensitivity analyses of fiscal or/and macroeconomic model (5), Budget circular (6), Independent reviews/analyses of macroeconomic and/or fiscal assumptions (7), pre-budget report (8), long-term perspective on total revenue and expenditure (9)

From 0 to 9 . Variable on elaborated on OECD data 
Table 5. Budget attributes of Belgium, Hungary and Norway

\begin{tabular}{|c|c|c|c|}
\hline Category & Belgium & Hungary & Norway \\
\hline \multicolumn{4}{|c|}{ I. General data } \\
\hline Type of state & Federal & Unitary & Unitary \\
\hline $\begin{array}{l}\text { Taxing power of sub-central } \\
\text { governments; OECD average: } \\
\left.15.4 \%{ }^{*}\right)\end{array}$ & $10.4 \%$ & $6.5 \%$ & $12.1 \%$ \\
\hline Economic/fiscal union membership & $\begin{array}{l}\text { European Union: Stability and Growth } \\
\text { pact }\end{array}$ & $\begin{array}{l}\text { European Union: Stability and Growth } \\
\text { pact }\end{array}$ & $\begin{array}{l}\text { Autonomous monetary and budgeting } \\
\text { policy }\end{array}$ \\
\hline \multicolumn{4}{|c|}{ II. Political-economy variables } \\
\hline Fiscal governance approach & Contract; Collegial rules prevail & Mixed: Contract and Delegation & Contract; Collegial rules prevail \\
\hline
\end{tabular}




\begin{tabular}{|c|c|c|c|}
\hline Government structure & $\begin{array}{l}\text { Coalition government: Flemish } \\
\text { Nationalists parties and the } \\
\text { Francophone parties, political system is } \\
\text { polarized. }\end{array}$ & $\begin{array}{l}\text { Multi-party system: conservative parties } \\
\text { Fidesz and KDNP hold the majority } \\
\text { starting from } 2011\end{array}$ & $\begin{array}{l}\text { Coalition government: } \\
\text { Labour Party, Socialist Left Party and } \\
\text { Centre Party }\end{array}$ \\
\hline Legislature power in budgeting & Unrestricted power to amend budget & Unrestricted power to amend budget & Unrestricted power to amend budget \\
\hline $\begin{array}{l}\text { Executive power to veto budget } \\
\text { approved by Legislature }\end{array}$ & No & No & No \\
\hline Status of minister of finance & Senior civil servant & Political appointee & Senior civil servant \\
\hline Resolution of budget disputes & Ministerial committees & Cabinet & Cabinet \\
\hline $\begin{array}{l}\text { Types and legal status of the fiscal } \\
\text { rules (FR) \% refer to GDP }\left({ }^{* \star}\right)\end{array}$ & $\begin{array}{l}\text { Budget Balance }(60 \%) \text { and debt }(3 \%) \text {. } \\
\text { FR are in the Constitution. Limit in } \\
\text { budget balance deficit of } 1 \% \text { in structural } \\
\text { terms. }\end{array}$ & $\begin{array}{l}\text { Debt }(60 \%) \text { FR is in the Constitution; } \\
\text { budget }(3 \%) \text { FR not in the Constitution. } \\
\text { Limit in budget balance deficit of } 1 \% \text { in } \\
\text { structural terms. }\end{array}$ & $\begin{array}{l}\text { Budget Balance FR is in national } \\
\text { legislation (not in the Constitution); limit } \\
\text { on structural budget balance, below } 4 \% \\
\text { of Government Pension Fund Global }\end{array}$ \\
\hline $\begin{array}{l}\text { CBA: } 1 . \text { Name; } \\
\text { 2. Mandate to monitor ministries; } \\
\text { 3. Main functions. }\end{array}$ & $\begin{array}{l}\text { Federal Public Service Budget } \\
\text { No } \\
\text { Preparation of budget circular, executive } \\
\text { budget proposal, reports, fixing ceilings } \\
\text { of ministerial budgets and conducting } \\
\text { negotiations, authorizing ministerial } \\
\text { outlays }\end{array}$ & $\begin{array}{l}\text { Ministry of Finance and Economy } \\
\text { No } \\
\text { Preparation of budget circular, executive } \\
\text { budget proposal, fixing ceilings of } \\
\text { ministerial budgets and conducting } \\
\text { negotiations in collaboration with } \\
\text { ministries }\end{array}$ & $\begin{array}{l}\text { Ministry of Finance } \\
\text { No } \\
\text { Preparation of budget circular, executive } \\
\text { budget proposal, reports } \\
\text { (does not fix ceilings of ministries, } \\
\text { testifying to legislature, ministries } \\
\text { request supplement budgets directly } \\
\text { with cabinet) }\end{array}$ \\
\hline Units that prepare macroeconomic & Independent bodies (National Accounts & Ministry of Finance and Economy & Ministry of Finance \\
\hline
\end{tabular}




\begin{tabular}{|c|c|c|c|}
\hline and fiscal projections & $\begin{array}{l}\text { Institute, High Council of Finance, } \\
\text { Federal Planning Bureau). }\end{array}$ & & \\
\hline \multicolumn{4}{|c|}{ III. Distinctive features of the national budget systems } \\
\hline $\begin{array}{l}\text { Model of budgetary decision } \\
\text { making }\end{array}$ & $\begin{array}{l}\text { Decentralized, with checks-and- } \\
\text { balances: National Accounts Institute, } \\
\text { High Council of Finance, Federal } \\
\text { Planning Bureau. }\end{array}$ & $\begin{array}{l}\text { Centralized but collaborative across } \\
\text { government with intent of involvement of } \\
\text { Fiscal Council }\end{array}$ & $\begin{array}{l}\text { Decentralized, favoring flexibility over } \\
\text { performance. The cabinet plays strong } \\
\text { role in the budgetary process }\end{array}$ \\
\hline $\begin{array}{l}\text { Organizational climate in the } \\
\text { budgetary process }\end{array}$ & $\begin{array}{l}\text { Transparency. Mutual supervision and } \\
\text { cooperative strategies among the three } \\
\text { bodies with responsibilities in the } \\
\text { budgetary process }\end{array}$ & $\begin{array}{l}\text { Professionalism. The post-soviet reform } \\
\text { of the civil service led to strong increase } \\
\text { in the professionalization of the civil } \\
\text { servants }\end{array}$ & $\begin{array}{l}\text { Trust. There is a high level of mutual } \\
\text { trust between the Ministry of Finance, } \\
\text { the spending ministries and the } \\
\text { independent agencies }\end{array}$ \\
\hline $\begin{array}{l}\text { The role of public-private bodies } \\
\text { and agencification in public sector } \\
\text { provision }\end{array}$ & $\begin{array}{l}\text { High levels of functional devolution: the } \\
\text { Government delegates some of its tasks } \\
\text { to semi-public bodies, particularly in } \\
\text { social security-related expenditures. }\end{array}$ & $\begin{array}{l}\text { Not significant, OECD recommends } \\
\text { strengthening their role; the Public } \\
\text { Procurement Office is placed under the } \\
\text { Parliament, not the Ministry }\end{array}$ & $\begin{array}{l}\text { Very important; } 17 \text { small ministries and } \\
180 \text { agencies. Over } 97 \% \text { of government } \\
\text { employees work in agencies. }\end{array}$ \\
\hline $\begin{array}{l}\text { Country specific, exogenous factors } \\
\text { with significant fiscal impact }\end{array}$ & NA & NA & $\begin{array}{l}\text { Proceeds from petroleum are fed into } \\
\text { the economy according to a pre- } \\
\text { established rule (Global Pension Fund- } \\
\text { Global) }\end{array}$ \\
\hline
\end{tabular}

Sources: based on OECD International Budget Practices and Procedures Database (2012), Anderson et al. (2006), Bogaert et al. (2006), Christiaens (2003), Evrard and Scutnaire (2006), Gajduschek, G. (2007), IMF (2008), Kraan et al. (2007), LeLoup (2000), Neshkova and Kostadinova (2012), Trondal (2014), OECD (2015). $\left({ }^{*}\right)$ States and local government tax revenue as \% of total tax revenue, 2011. Source. OECD Fiscal Decentralization database. $\left({ }^{* *}\right)$ Source. OECD 2012 Survey of Budgeting Practices. 